\title{
Determinants of Smallholder Commercialization of Tomato Crop in Siltie Zone, Southern Ethiopia
}

\author{
Bahilu Ejeta $^{1, \text { * }}$, Derebe Ermias ${ }^{1}$, Gosaye Ashetu ${ }^{1,2}$ \\ ${ }^{1}$ Department of Agricultural Economics, Werabe University, Werabe, Ethiopia \\ ${ }^{2}$ Department of Plant Science, Werabe University, Werabe, Ethiopia
}

Email address:

bahiluejeta2019@gmail.com (B. Ejeta), chakiso4979@gmail.com (D. Ermias), gosaayee@gmail.com (G. Ashetu)

${ }^{*}$ Corresponding author

\section{To cite this article:}

Bahilu Ejeta, Derebe Ermias Gosaye Eshetu. Determinants of Smallholder Commercialization of Tomato Crop in Siltie Zone, Southern Ethiopia. Agriculture, Forestry and Fisheries. Vol. 9, No. 6, 2020, pp. 163-173. doi: 10.11648/j.aff.20200906.12

Received: September 22, 2020; Accepted: October 12, 2020; Published: November 4, 2020

\begin{abstract}
The productivity of agricultural resources was very low; especially in the developing world where production is common on fragile lands and characterized by small-scale subsistence farming. Commercialization of agriculture provides farm households with a means to alleviate poverty and food insecurity by generating incomes in the rural areas. This paper aims to identify factors affecting commercialization of tomato crop by smallholder farmers in Siltie Zone, Southern Ethiopia. Both structured and unstructured questionnaires and Focus Group Discussion were used to collect data from 175 respondents randomly selected from designated locations in the study area. Descriptive statistics and heckman two stage models were used to analyze the collected data. According to first stage Heckman selection estimation (probit regression) model result, Education, frequency of extension contact, distance to market, market agreement and lagged price played a significant role in smallholder commercialization decision. In the second-stage of Heckman selection estimation family size, education, land allocated for tomato production, frequency of agricultural extension contact, distance to nearest market, productivity, lagged price and inverse mill's ratio were significantly affect level of tomato commercialization. Thus, the study recommends the need for designing appropriate intervention mechanisms focusing on the abovementioned factors so as to improve the performance of tomato crop commercialization.
\end{abstract}

Keywords: Commercialization, Heckman Two Stage Models, Tomato, Smallholder

\section{Introduction}

Tomato (Lycopersicon esculentum Mill.) is one of the most important edible and nutritious vegetable crops in the world. It ranks next to potato and sweet potato with respect to world vegetable production but ranks first as a processing crop [5, 26]. It is widely cultivated in tropical, subtropical and temperate climates and the leading top ten tomato producing countries are China, India, Turkey, United State of America, Egypt, Iran, Italy, Spain, Mexico and Brazil [13]. As it is a relatively short duration crop and gives a high yield, the crop is economically attractive and the area under cultivation is increasing daily. The current world tomato production reached to more than 182.2 million tons cultivated on more than 4.7 million hectares of land [13].

The climatic and soil conditions of Ethiopia are suitable for the production of a wide range of tropical and subtropical fruits and vegetables including tomato. According to [13] the annual average tomato production in Ethiopia is estimated to be about 43,816 tons which is harvested from about 7,089 hectares of land. Although Ethiopia has huge potential, yet average productivity of tomato in the country is very low, that is 6.18 tons $^{1} /$ ha compared with average productivity of 16, 96.8, 63.9, 43 and 38.3 tons/ha in Africa, America, Europe, Asia and the entire world, respectively [13]. Currently tomato is one of the regional export crops of the country $[15,6]$.

The tomato crop is mainly cultivated by smallholder

1 ton is equal to 10 quintal. 
farmers as cash crop in mid- to low-altitude areas of Ethiopia. It is one of widely grown vegetable crop as annual both in the rainy and dry seasons for their fruits by smallholder farmers, commercial state and private farms in Ethiopia [15, 28, 4]. The crop is grown between 700 and 2000 meters above sea level, with about 700 to over 1400 $\mathrm{mm}$ annual rain fall, in different areas and seasons, in different soils, under different weather conditions, but also at different levels of technology (e.g. with furrow, drip or spate irrigation) and yields [7, 15, 6].

Production of tomato has been emphasized as a source of food security and income in many countries [37]. It has very wide importance both as a source of food and health care i.e. it constitutes vitamins like vitamin $\mathrm{A}$ and $\mathrm{C}$ which play an important role in human health and is widely consumed in every household in different modes including raw, as an ingredient in many dishes, sauces, stews, salads, and drinks. Tomatoes also contain lycopene, a red pigment serving as a natural anti-oxidant, calcium, water, and niacin, which are essential for metabolism [36]. Such diverse uses make the tomato an important vegetable crop in Ethiopia and the production is rapidly increasing in many parts of the country.

Food security continues to be a problem in Ethiopia as it is the situation in a number of Sub-Saharan African countries. One important step towards achieving food security could be increasing productivity through enhancing efficiency in production (Wudineh and Endrias, 2016). On other hand to enhance productivity of agricultural production, commercialization of smallholder agricultural producers through increased participation in output markets has been one of the best strategy [35, 41, 31] Southern Nations and Nationalities Peoples Regional State (SNNPRS) in general and Siltie Zone in particular have diverse agro ecology and many areas are suitable for growing horticultural crops including tomato. Despite the potential of the District for vegetable production, its productivity is low due to use of low level of improved agricultural technologies, risks associated with climatic conditions, diseases and pests. Moreover, the nature of the product on one hand and lack of organized market system on the other hand frequently resulted in low producers' price [27].

According to literature review, there have been different empirical studies conducted earlier on commercialization of smallholder horticultural crops. For instance Melese et al. (2018) on determinants of commercialization by smallholder onion farmers in Fogera district, South Gondar Zone, Amhara regional State; [20] on determinants of smallholder market participation among banana growers in bench Maji Zone, Southwest Ethiopia; [3] on commercial behaviors of smallholder potato producers in case of Kombolcha woreda, Eastern part of Ethiopia; [1] on determinants of smallholder farmers participation decision in potato market in Kofele district, Oromia regional state; [25] on smallholder market participation and its associated factors evidence from Ethiopian vegetable producers; [39] on determinants of commercialization of agricultural products in East and West
Gojjam, and Awi Zones, Amahara Region, Ethiopia. Although several studies have been conducted on commercialization of smallholder agricultural products, very little is known about commercialization of tomato crop in Siltie Zone. Furthermore, all those finding may not applicable to the case of tomato production and marketing in Siltie Zone due to diverse agro-ecological zone, difference in infrastructural and service distribution and differences in technology adoption. Thus, this study was intended to fill this gap with the aim of identifying determinant factors of smallholder commercialization of tomato output in Siltie Zone, Southern Ethiopia.

\section{Analytical Framework of Commercialization}

Most recent literatures adopt, Tobit, Heckman's two stage and Double hurdle models to examine crop market participation [21]. Heckman two-stage model was developed by [19] and has developed a two-step estimation procedure model that corrects for sample selectivity bias. Since participation in tomato marketing is represented by a binary variable, those who participate may be not sale all their tomato products which implies that the decision to sell and the decision of how much to sell are two separate decisions. In Heckman two-stage model the decision to participate can alternatively be modeled as two separate processes. The model first uses a probit regression with all variables to estimate the probability of participation. Then the inverse mills ratio is computed from the probit regression and is used as a regressor with other explanatory variables to explain the outcome of dependent variable.

The choice of Heckman two stage models is related with the advantages compared to Tobit model and it allows the determinant factors to vary for participation and level of participation. So that to determine the factors influencing participation and extent of participation in tomato marketing, the Heckman two-stage selection models will be used. The decisions to either participate in the market or not and level of participation were dependent variables and will be estimated simultaneously. Heckman two-step model involved estimation of two equations: first, is whether a household participated in the tomato market or not, and the second is the extent of market participation (proportion of tomato sales). The proportion of tomato sales is conditional on the decision to participate in the market. Heckman procedure is a relatively simple procedure for correcting sample selection bias with the popular usage.

Double hurdle model was first introduced as a class of models by [9]. The modeling approach assumes a two-step decision process. This is based on the assumption that household makes two separate decisions; the first step involves the decision whether to participate in the market or not participate and secondly the extent of participation. The model estimation involves a probit regression to identify factors affecting the decision to participate in the market by 
using all sample households in the first stage, and a truncated regression model on the participating households to analyze the extent of participation, in the second stage. The limitation of the model is it does not capture sample selection bias when error of the selection and outcome equation are dependent or correlated $[23,16]$.

Tobit model is a statistical model proposed by [40]. Tobit model is a special case of censored regression models that arise when the dependent variable is limited (or censored) from above and/or below. In many cases a Probit or Logit model is specified to explain whether or not farmers commercialize without considering the intensity of commercialization. The Probit or Logit models cannot handle the case of commercialization that has a continuous value range. One approach of addressing the problem is use of Tobit model which interprets the zero observation as corner solution and addresses the intensity of commercialization [16].

\section{Materials and Methods}

\subsection{Description of the Study Area}

Siltie administrative zone has a total area of 3000 sq. km and for administrative purpose; it is structured in to ten districts and one urban town. These include Silti, Misrak Silti, Dalocha, Lanfro, Sankurra, Hulbareg, Mito, Misrak Hazernet, Mirab Hazernet, and Alicho. Worabe town is the administrative center of the zone which is found $173 \mathrm{kms}$ from Addis Ababa [38]. The land scape of the zone is fairly level and found in northern part of SNNPRS and located in the North West of Alaba zone, North East of Hadiya zone, West of Oromia and South, South West and South East of Gurage zone. The zone can be classified into three major climatic zones on the basis of altitude, rainfall and temperature: $20.6 \%$ Dega, $74.4 \%$ Woina-Dega and 5\% Kolla of the total area of the region. Mean annual temperature is between $12-26 \mathrm{C}^{\circ}$. The rainfall is between 700 and $1818 \mathrm{~mm}$. Agriculture is the main economic activity and the zone has varied ecological zones that range from lowland to highland, which makes possible the cultivation of various crop. The agricultural sector is characterized by less diversity, low productivity and low agricultural technologies, lack of adequate marketing and other infrastructure facilities. The main economic source of livelihood is based on both crop production and livestock rising. Crops which are grown for food consumption as well as for income source in the area are enset, wheat, barley, maize, bean, pea, haricot bean, beetroot, potato, tomato, paper, onion, garlic, cabbage, and some other garden spices. Further, oxen and sheep fattening for holidays of the year is very common serving as an alternative source of income generating strategy of farmers in Siltie zone.

\subsection{Data Type and Source of Data}

The study used household survey data that was collected from tomato producers in the study area. Both qualitative and quantitative data were collected from secondary and primary sources. Primary data included both situations of production and marketing system from the producing farmers. The primary data collected from tomato producers focused on demographic characteristics of the household, farming experience, livestock owned, size of land allocated to tomato production, distance to the nearest market, access to credit service, frequency of extension contact, non/offfarm income, lagged market prices of tomato, current market price of tomato, cooperative membership, quantity produced and quantity sold. Besides, secondary data on total land size, price data, area coverage, and challenges, tomato crops growing peasant associations and population types were collected from unpublished and published materials.

\subsection{Sampling Size and Sample Techniques}

To select representative sample size from tomato producers, a three stage sampling techniques were used. In the selection process district agricultural office experts were consulted. In the first stage, two districts were selected purposively based on tomato crop production potential. The selected districts are Silti and Misrak Silti. In the second stage, three kebeles from each district were selected purposively. Then respondents sample size was selected from each Kebele using random sample selection technique proportional to its household size. The sample frame of the study was the list of household obtained in each kebele of agricultural office. Finally, 175 sample sizes from producers were selected by using random sampling technique and interviewed for the study. In calculating sample size, if there is no previous related work, pilot survey is recommendable and will provide necessary information to fix the value of P. However, for the current study, due to budget and time constraint, the researchers could not carryout pilot survey. Therefore, the following assumption is used regarding the value of $\mathrm{P}$. When calculating sample size for proportion, there are two situations to consider. First, if some approximation of $\mathrm{P}$ is known (example, from a previous study), that value can be used in the formula. Second, if no approximation of $P$ is known, one should use $P=0.5$. This value will give a sample size sufficiently large to guarantee an accurate prediction.

Thus, in this study, $\mathrm{p}=0.5$ was used. This is because of absence of previous study approximation for $p$ value.

The required sample size was determined by [8] proportionate to size sampling.

$$
\mathrm{n}=\frac{\mathrm{z}^{2} \mathrm{pq}}{\mathrm{e}^{2}}
$$

Where; $n=$ Sample size; $Z=$ confidence level $(\alpha=0.05)$; $p=$ proportion of the population containing the major interest, $\mathrm{q}=1-\mathrm{p}$ and $\mathrm{e}=$ allowable error $(0.07)$. Hence, $Z=$ 1.96

$$
\mathrm{n}=\frac{\mathrm{z}^{2} \mathrm{pq}}{\mathrm{e}^{2}}=\frac{1.96^{2}(0.5)(0.5)}{0.07^{2}}=175
$$




\subsection{Method of Data Analysis}

Econometric model is used to identify the factors that affect farmer's commercialization decision in tomato marketing in one hand and extent of commercialization in tomato marketing in the other hand. Most recent literatures adopt, Tobit, Heckman's two stage and Double hurdle models to examine crop market participation [21,27]. The choice of Heckman two stage models is related with the advantages compared to Tobit model and it allows the determinant factors to vary for participation and level of participation. So that to determine the factors influencing participation and extent of participation in tomato marketing, the Heckman two-step selection models was used. The decisions either participate in the market or not and level of participation were dependent variables and were estimated simultaneously. Heckman two-step model involved estimation of two equations: first, is whether a household participated in the tomato market or not, and the second is the extent of market participation (proportion of tomato sales). The proportion of tomato sales is conditional on the decision to participate in the market. Heckman procedure is a relatively simple procedure for correcting sample selection bias with the popular usage. The specifications for Heckman's two step selection models are as follows: (i) The participation equation: the Probit model is specified as:

$$
\begin{gathered}
Y_{i}=B_{i} X_{i}+e_{i} \\
y_{i}=\left\{\begin{array}{l}
1 \text { if } y_{i}^{*}>0 \\
0 \text { if } y_{i}^{*} \leq 0
\end{array}\right\} i=1,2.3 \ldots n
\end{gathered}
$$

Where, $\mathrm{Yi}^{*}$ is the latent dependent variable which is not observed and $\mathrm{Yi}$ is binary variables that assumes 1 if small scale tomato farmers $i$, that participate in the marketing and 0 other wise.

$X_{\mathrm{i}}=$ is a vector of independent variables hypothesized to affect household decision to participate in tomato market.

$\mathrm{B}_{\mathrm{i}}=$ is a vector of parameters to be estimated is normally distributed disturbance with mean (0) and

$\mathrm{e}_{\mathrm{i}}=$ standard deviation of 1 and captures all unmeasured variables

According to $[11,27]$, in this study the market participation decision is estimated as $\mathrm{Y}=1$ if the household participates in output markets and $\mathrm{Y}=0$ otherwise. Following von [27] the researcher can compute household crop output market participation in annual crops as the proportion of the value of crop sales to total value of crop production, which can be computed as follows:

$$
M P_{I}=\frac{P S}{P Q}
$$

Where MP is Market participation, PS is total value of tomato sales and PQ is total value of tomato produce. Given the nature of market participation level, the farmers are said to be market participant if their proportion of value sold is more than $75 \%[32,34,27]$. Thus, the researchers defined the binary response variable as $\mathrm{Y}=1$ if the farmer's tomato sales exceed a threshold or critical level of $\mathrm{Y}^{*}(75 \%)$ and $\mathrm{Y}=0$ if $\mathrm{Y} \leq \mathrm{Y}^{*}$. Here, the proportion of tomato sold (say, above $75 \%$ ) out of the total production by the smallholder farmers in the production year was used as the proxy of market participation during data collection period [14, 30, 27].

(ii) Regression (OLS): Selection model is specified as:

$$
\mathrm{Q}_{\mathrm{i}}=\alpha_{i} Z_{i}+\mu \lambda_{\mathrm{i}}+\eta_{\mathrm{i}}
$$

Where, $\mathrm{Qi}=$ is the proportion of tomato supplied to market; $\alpha_{i}=$ is a vector of unknown parameter to be estimated in quantity supply equation,

$Z_{\mathrm{i}}=$ is vector of explanatory variables determining the quantity supplied;

$\mu=$ is parameter that helps to test if there is a self-selection bias in market participation;

$\eta_{\mathrm{i}}=$ is the error term.

$\lambda_{\mathrm{i}}=$ Lambda, which is related to the conditional probability that an individual household decide to participate (given a set of independent variables), is determined by the formula

$$
\lambda_{i}=\frac{f(x \beta)}{1-f(x \beta)}
$$

Where, $f(x \beta)$ is density function and $1-f(x \beta)$ is distribution function.

Before fitting important variables in the models, it is necessary to test multicollinearity, heteroscedasticity and normality problem among the variables which seriously affects the parameter estimates. Several methods of detecting the problem of multicollinearity have been used in various studies. Two measures are often suggested in the discussion of multicollinearity which is the variance inflation (VIF) factor for continuous variables and contingency coefficient for dummy variables (Tables A1 and A2).

\section{Results and Discussion}

\subsection{Characteristics of Households by Market Participation}

The collected data from 175 tomato farmers were analyzed to depict the demographic, economic and institution characteristics of tomato growers in the districts. Among the sampled farmers, 57.71 percent were tomato market participants while 42.29 percent were non-market participants. Descriptive statistics (percentages, mean, t-test and chi-square test) indicated that Market participants and non-market participants had statistical significant differences with regards to Education level of household head, Family size, Land allotted for tomato, Frequency of visits by extension agents, Productivity, Distance to nearest market, Access to credit and Market agreement. The key features of the variables used in the current research are shown in the Tables 1 and 2. 
Table 1. Mean household characteristics by market participation decision.

\begin{tabular}{llll}
\hline \multirow{2}{*}{ Variables } & Mean value of variables for & & \\
\cline { 2 - 4 } & Not market participants & Market participants & Both \\
\hline Age of household head & 41.89 & 40.97 & 41.36 \\
Education level of HH in years & 3.73 & 4.66 & 0.67 \\
Family size in adult equivalence & 3.36 & 4.06 & $-1.89 * *$ \\
Land allotted for tomato & 0.21 & 0.25 & 3.76 \\
Frequency of extension contact & 4.11 & 7.39 & 0.23 \\
Distance of nearest market & 1.02 & 0.723 & 6.00 \\
Productivity & 140.91 & 167.52 & 0.85 \\
Livestock in TLU & 3.87 & 3.91 & $-4.15 * *$ \\
Number of oxen owned & 1.46 & 1.54 & $-2.48 * *$ \\
\hline
\end{tabular}

Notes: $* * *, * *, *$ denote the level of significance at 1,5 , and 10 percent, respectively.

Source: Model results of survey data (2019/2020).

Descriptive analyses of the sample households show that the average size of land allocated for tomato crop among participants was 0.25 ha and 0.21 ha among nonparticipants and 0.23 ha in total sample respondents. The value of t-test (2.48) shows that there was a significant difference in the mean size of land allocated for tomato production between participants and non-participants at less than 5\% level of significance. Educated households may be better able to acquire and process information. From the sample household heads, 3.73 years of schooling is for not market participants and 4.66 years of schooling is for market participants. In terms of household size, the results indicate that the mean of the household size adult equivalent for the market participants was found to be 4.06 while that for non-market participants was found to be 3.36. In terms of tomato yield, the means of tomato yields for market participants was found to be 140.91 quintals per hectare while that for non-market participant was found to be 167.52 quintal per hectare. The mean of overall tomato yield was found to be 156.27 quintal per hectare. The result of the two tailed tests showed that the tomato yield was statistically significant at $1 \%$ indicating that the market participants had more tomato yields than nonmarket participants. Farmers travelled the average distance of 0.85 hours to reach the nearest market. The extension visits and interaction with extension agents is a way adopting improved technology adoption, information access and hence reduces information costs. Additionally, the roles of extension agents were to increase improved of agricultural technology adoption among smallholder farmers in order to boost the volume of production. Table 1 results confess that the market participants contact with extension agent 7.39 times within one production season where as non- market participants contact 4.11 times.

Table 2. Proportion of household characteristics by market participation.

\begin{tabular}{lllll}
\hline Variables & Category & Not market participant (\%) & Market participant (\%) & Both \\
\hline \multirow{2}{*}{ Sex } & Female & $5(2.8 \%)$ & $8(4.57 \%)$ & $13(7.43 \%)$ \\
& Male & $66(37.71 \%$ & $96(54.86)$ & $162(92.57 \%)$ \\
Off farm activities & Yes & $17(9.71 \%)$ & $20(11.43 \%$ & $37(21.14 \%)$ \\
& No & $57(32.57 \%)$ & $81(46.29 \%)$ & $138(78.86 \%)$ \\
Access to credit & Yes & $4(2.29 \%$ & $26(14.86 \%)$ & $30(17.14 \%)$ \\
Marketing & No & $70(40 \%)$ & $75(42.86 \%)$ & $145(82.86 \%)$ \\
agreement & Yes & $12(6.86 \%)$ & $47(26.86 \%)$ & $59(33.71 \%)$ \\
\hline
\end{tabular}

Notes: $* * *, * *, *$ denote the level of significance at 1,5 , and 10 percent, respectively.

Source: Source: Field survey results $(2019 / 2020)$.

The chi-square result shows that the access to credit was statistically significant at $1 \%$ indicating that more of market participants have access to credit and enter to market agreement than non-market participants. Marketing agreement has been perceived to increase market participation because the farmers are assured of the ready market for their produce. In terms of access to credit, the result shows that $14.86 \%$ of market participants had an access to credit while $42.86 \%$ did not access.

\subsection{Determinants of Tomato Crop Output Commercialization}

First-stage probit estimation results on factors affecting the probability of tomato market participation: Heckman's two step model was used to analyze the factors affecting smallholder tomato growers' market participation. The first stage of the Heckman selection model or the probit model was employed to identify factors influencing tomato market participation decision of households in the study area. Average marginal effect was used in this study as a useful measure to interpret the result as the coefficient of probit model is difficult to interpret since it only shows the direction of the effect. The likelihood ratio test indicates that, the overall goodness of fit of the probit model is statistically significant at less than $1 \%$ probability level. This indicates that the explanatory variables included into the probit model regression jointly explain the variations in the tomato producers' probability to participate in tomato market. 
Pseudo $\mathrm{R}^{2}$ is calculated and the obtained values indicate that the independent variables included in the regression explain significant proportion of the variations in the tomato farmer's likelihood to participate in tomato market. Last, the model results indicated that out of 16 explanatory variables, five variables explained probability of tomato market participation. These variables are education level of household head, frequency of extension contact, distance to nearest market in walking hours, market agreement and condition of lagged price in last production year.

Table 3. First-stage probit estimation results on factors affecting tomato market participation decision.

\begin{tabular}{|c|c|c|c|c|c|}
\hline Variables & Coef. & Std. Err. & $\mathbf{Z}$ & $\mathbf{P}>\mathbf{Z}$ & Marginal effect (dy/dx) \\
\hline Sex* & -0.149 & 0.410 & -0.36 & 0.716 & -0.053 \\
\hline Age square & 0.076 & 0.222 & 0.34 & 0.733 & 0.027 \\
\hline Education & $0.089^{*}$ & 0.049 & 1.80 & 0.072 & 0.032 \\
\hline Family size & 0.175 & 0.125 & 1.39 & 0.164 & 0.063 \\
\hline Farm size & 0.615 & 1.521 & 0.40 & 0.686 & 0.224 \\
\hline Credit* & 0.491 & 0.385 & 1.27 & 0.203 & 0.169 \\
\hline Non-farm income* & -0.425 & 0.327 & -1.30 & 0.194 & -0.161 \\
\hline Market distance & $-0.873^{* *}$ & 0.364 & -2.40 & 0.017 & -0.318 \\
\hline Farm experience & 0.054 & 0.053 & 1.03 & 0.304 & 0.020 \\
\hline Productivity & -0.0008 & 0.0027 & -0.30 & 0.763 & -0.0003 \\
\hline Membership coop* & 0.126 & 0.319 & 0.40 & 0.693 & 0.045 \\
\hline Livestock & -0.0169 & 0.107 & -0.16 & 0.875 & -0.006 \\
\hline Oxen & -0.172 & 0.197 & -0.87 & 0.382 & -0.063 \\
\hline Market agreement* & $0.618^{* *}$ & 0.315 & 1.96 & 0.050 & 0.212 \\
\hline cons & -1.891 & 1.487 & -1.27 & 0.204 & \\
\hline \multicolumn{6}{|c|}{$\bar{L}$ Log likelihood $=-72.946108$} \\
\hline \multicolumn{6}{|c|}{ LR chi2 $(16)=93.13$} \\
\hline \multicolumn{6}{|l|}{ Prob $>$ chi $2=0.0000$} \\
\hline \multicolumn{6}{|l|}{ Pseudo R2 = 0.3896} \\
\hline Number of obs $=175$ & & & & & \\
\hline
\end{tabular}

$(*) \mathrm{dy} / \mathrm{dx}$ is for discrete change of dummy variable from 0 to 1 .

Note. $* * *=1 \%, * *=5 \%$ and $*=10 \%$ significance level.

Source: Model results of survey data (2019/2020).

Education level of $\mathrm{HH}$ : The positive effect of education level of household head implies that, education empowers the farmer to access more information and new existing opportunities from various markets. This makes a farmer with more education to be more informed on market requirements in terms of price, quality, and right volume of tomato needed by buyers and thus becomes very likely to participate in the marketing activities. This is because having more market information reduces the searching and bargaining costs that smallholder farmers incur in the process of finding the right buyer. On the other hand, farmers with no education are less informed about market information and hence they find it very difficult to participate into the market due to high fixed transaction costs. The marginal effect also confirmed that, if the year of schooling of household head is increased by one year, the probability to participate in tomato market increases by $3.2 \%$. These finds are consistence to those of [35] who found that, in Nigeria smallholder farmers with high level of education were more involved in selling their produce to market.

Distance to nearest market: It was expected to negatively affect market participation decision. As the result of probit model in Table 3 revealed that distance to nearest market was found to have negative significant influence on the probability of smallholder farmers to participate in the tomato output market. The sign negative means that as distance to nearest market increases, the probability of farm household's towards commercialization of their farming system reduces in the study area. This is because as the distance to nearest market increases, the transportation cost increases as well, this is a hindrance to market participation. The marginal effect revealed that as the distance to nearest market increase by one hour, the probability of household to participate in the output market decreases by $31.8 \%$. This finding concurs with the finding of $[24,24]$ who reported that farmers' decision on market entry is negatively and significantly related to the market participation.

Frequency of extension contact: It is also found that frequency of contact with extension agents is positively and significantly influencing the probability of selling tomato at $1 \%$ significance level. The roles of extension agents were to improve of agricultural technology adoption among smallholder farmers in order to boost the volume of production. In addition, extension service delivered in the area in relation to the agronomic practices producers had to perform contributed positively in enhancing the productivity of tomato in the area. Marginal effect exposes, being more contact with extension specialists increases the probability to participate in the tomato market by $4.2 \%$. This result is consistent with $[27,42]$ access to extension service was negatively and significantly associated with crop sale volume.

Tomato lagged price: It is another variable which was found to significantly affect market participation decision of tomato producers at $1 \%$ level of significance in this study. 
Price is the crucial instrument in marketing because lower price is a disincentive to market participation. The results showed if the former price (price of 2018/2019) is good enough, the probability to participate in the output market will increase by $38.1 \%$ in the study area. This result is in line with [12] that found the price has positive significant relationship with market participation decision in the market.

Market agreement: This variable significantly and positively influences market participation at $10 \%$ significance level. This implies that as contract-marketing increase, the probability of participation in tomato market increases by $21.2 \%$. This result contrasts with prior expectation and the findings of [27]. The reasons behind that most of farmers were under contract and the ready market did absorb maximum products their tomato produce. Moreover, it will minimize the burden of searching other market and perishability of the product.

Results of second-stage Heckman selection estimation on factors affecting the volume of supply: The overall joint goodness of fit for the Heckman selection model parameter estimates is assessed based on the likelihood ratio test. The null hypothesis for the likelihood ratio test is that all coefficients are jointly zero. The model chi-square tests applying appropriate degrees of freedom indicate that the overall goodness of fit for the Heckman selection model is statistically significant at less than $1 \%$ probability level. This shows that jointly the independent variables included in the selection model regression explain the marketed surplus. To determine factors influencing marketable supply, second stage of Heckman selection (OLS) model was employed. In the second stage selection model, nine explanatory variables: education, family size, tomato land allotted, productivity, frequency of extension contact, market distance, market agreement, lagged price and lambda affected volume of tomato supply.

Table 4. Results of second-stage Heckman selection estimation on factors affecting the volume of supply.

\begin{tabular}{llll}
\hline \multirow{2}{*}{ Variables } & Robust & & Ptd. Err. \\
\cline { 2 - 3 } & Coef. & 1.119 & 0.219 \\
\hline Sex & -1.380 & 0.837 & 0.194 \\
Age squared & 1.092 & 0.172 & 0.001 \\
Education & $0.599^{* * *}$ & 0.530 & 0.002 \\
Family size & $1.639^{* * *}$ & 7.006 & 0.000 \\
Land size & $93.903^{* * *}$ & 1.422 & 0.108 \\
Credit & 2.298 & 1.305 & 0.491 \\
Non-farm income & -0.901 & 0.255 & 0.001 \\
Extension contact & $0.845^{* * *}$ & 1.854 & 0.001 \\
Market distance & $-6.344^{* * *}$ & 0.209 & 0.234 \\
Farm experience & 0.250 & 0.0129 & 0.000 \\
Productivity & $0.142^{* * *}$ & 0.386 & 0.114 \\
Livestock & -0.613 & 1.276 & 0.002 \\
Market agreement & $4.034^{* * *}$ & 1.954 & 0.001 \\
Lagged Price & $6.576^{* * *}$ & 2.453 & 0.013 \\
LAMBDA & $6.196^{* *}$ & 6.675 & 0.000 \\
cons & $-40.552^{* * *}$ & & \\
rho $\mid$ & 1.00000 & & \\
Sigma & 12.343 & & \\
Number of obs & $=175$ & & \\
Censored obs & $=75$ & & \\
Uncensored obs & $=100$ & & \\
Wald chi2 (14) & $=171.78$ & & \\
Prob $>$ chi2 & $=0.0000$ & & \\
\hline
\end{tabular}

Note: $* * *$ and $* *$ show the values statistically significant at $1 \%$ and $5 \%$ probability level respectively.

Source: Model results $(2019 / 2020)$.

Family size: Also the increase in the size of households will imply more supply of labor and thus more tomato will be produced by those households. This in turn will increase the likelihood of the farmers to decide quickly to participate in the market and sell more tomato. Table 4 reveals that the variable 'family size' is statistically significant at $1 \%$ level and has positive influence on the level of market participation of households. This means that as the family size increases, the volume supplied to a market increases. This is due to the role of family size in boosting total production level and thus sales of surplus produce. Moreover, farm households with large farm size could allocate their land partly for food crop production and partly for cash crop production giving them better position to participate in the output market. This result is in line with $[17,34]$.

Education level of HH: Literacy has showed positive effect on tomato quantity sold with significance level at $1 \%$. On average, if tomato producer gets educated, the amount of tomato supplied to the market increases by 0.59 quintal. The result further indicated that, education has improved the producing household ability to acquire new idea in relation to market information and improved production, which in turn enhanced productivity and thereby increased marketable supply of tomato. This is in line with [27] who illustrated that if onion producer gets educated, the amount of onion supplied to the market increases, which suggests that 
education improves level of sales and thus affects marketable surplus.

Land allocated for tomato production: As expected, proportion of land allocated for tomato production had a positive and significant influence on the level of tomato sold at less than $1 \%$ probability level of significance. The implication is that the farmers having large size land plot for tomato can produce more tomato through by adopting new technologies for surplus amount of production and also encourage level of marketable surplus. Data in Table 4 shows that a land allocated for tomato production increases in hectare increases the level of tomato sold by 93.9 quintals. This result is in agreement with the finding reported by [2, $29,22,27]$ which show that proportion of land allocated for output production positively affected marketable surplus of outputs.

Frequency of extension contact: As hypothesized frequency of agricultural extension contact per year significantly and positively influence the level of supplied to market at less than $1 \%$ level of significance. From Table 4, an increase in the agricultural extension contact increased the marketable supply by 0.84 quintal. This finding is confirmed with the finding of $[34,22]$ that Agricultural extension services appear effective in inducing market orientation for smallholder farmers.

Productivity: As hypothesized, result shows that marketed surplus was significantly affected by tomato yield at less than $1 \%$. The positive coefficient indicates that a unit increase in tomato yield produced will increase the marketable supply of farmers. The result also implies that, a unit increase in the tomato yield produced can cause an increase of $0.14 \mathrm{qt}$ (quintal) of marketable tomato. This denotes farmers' with higher productivity (yield) are willing to supply more farm output in market. This is in line [27] who illustrated an increase of onion yield, increased marketable supply of the commodities significantly.

Market distance to nearest urban center: As expected, the survey results showed that distance from the district market is negatively related with level of tomato crop supplied to market at $1 \%$ significance level. The result could be attributed to the fact that the farther away a farmer is from the market, the more difficult and costly it is to get involved. An increase in walking hour by 1 hour decreases the level of tomato crop supplied to market by $6.34 \mathrm{qt}$. This finding is confirmed with the study conducted by [22] who found that being closer to the market enhanced market participation.

Market agreement: The coefficient of contract marketing was found to be positive and strongly significant. Being in contract marketing increases the volume of tomato sale by 4.034qt. This denotes that the farmers who were marketing under contract sold more of tomato produce due to availability of ready market. The finding is in line with that of [21, 27] who found an increase in formal market participation with the availability of contractual agreement amongst smallholder and emerging farmers in the Kat river valley, South Africa and in the Ethiopia respectively.

Lagged price: Lagged price significantly and positively influenced the extent of market participation at $1 \%$. The results showed if the former price (price of 2018/2019) is good enough, the volume supplied in the output market will increase by $6.57 \mathrm{qt}$ in the study area. These study findings are consistent with the economic theory, law of supply, which stipulates that the increase in price of good leads to the increase in quantity supplied. [20] Found a positive significant relationship between price and quantity of food beans supplied to market in Nyanza District of Southern Province, Rwanda.

Inverse Mill's Ratio: It was significant and positively related to the level of tomato commercialization at less than $10 \%$ significance level, which implies that there are unobserved factors that might affect both probability of tomato farm households' market participation decision and marketed surplus. This confess that, there is sample selection bias; which implies the existence of some unobserved factors responsible for tomato growers' likelihood to participate in market and thereby the level of market participation. The positive sign of lambda shows that there are unobserved factors that are positively affecting both participation decision and marketed surplus of tomato. The sign of rho is positive, indicates that unobserved factors are positively correlated with one another. Sigma $=12.34$ represents the adjusted standard error for the level of market participation equation regression; and the correlation coefficient between the unobserved factors that affecting decision in to market participation and unobservable that affecting participation level is given by $\mathrm{rho}=1.00000$.

\section{Conclusion and Recommendations}

\subsection{Conclusion}

Transforming the subsistence-oriented production system into a market-oriented production system is vital to improve the smallholder farmer's livelihoods and reduce rural poverty. Silti and Misrak Silti are potential tomato crop producing districts found in Siltie Zone, Southern Ethiopia. However, the productivity and market participation of tomato in these districts was limited. This study has sought to investigate and assess factors determining of tomato crop commercialization among smallholder farmers in these two districts. In this study, since tomato is commercial crop, smallholder tomato producers who supply more than $75 \%$ of their produce to the market are considered as market participant. According to first stage Heckman two step selection model, education level of household head, lagged price, frequency of extension contact, market agreement and market distance are important factors which determine the decision in tomato market participation. When previous year price is attractive enough, tomato producers motivated to produce more and supply more. On the other hand, frequency of extension contact has a great impact on tomato commercialization. If extension agents support smallholders from the point of production to post harvest management, producers easily can be commercialized producers rather 
than subsistence farmers. Market distance also affects market participation decision negatively. As distant to the market increases, smallholder farmers' participation to the market decreases. This factor is also related with road and transport problems.

According to second stage Heckman selection model, education level, household size, area for tomato cultivation, frequency of extension contact, market distance, productivity, market agreement and lagged price are important determinant of the level of tomato crop commercialization. The size of land allocated for tomato crop affected the smallholder commercialization of tomato crops positively and significantly. However, increasing the size of landholding cannot be an option to increase horticultural crops supply since land is a finite resource. Therefore, intervention aims to increase productivity of horticultural crops per unit area of land through proper utilization of land resource in the district. Increasing the productivity of horticultural crops per unit area of land through promoting and delivering technology packages to smallholders that would increase productivity of smallholders and enables them to link up with crops output market would be a better alternative for smallholder commercialization. This intensification of agricultural production should be supported with small scale irrigation development to increase the cropping intensity as to enhance the comparative advantage of smallholders in the production of horticultural crops. Thus, in order to improve livelihood of the society concerned body should have to work on both productivity increment and marketing aspect.

\subsection{Recommendations}

Government and other concerned bodies should have to assist smallholder farmers based on the following policy direction.

Provision of extension service and access to farmers' cooperatives should be strengthened, improved and support producers to become market oriented and participant for the supply of inputs and output marketing. This joint effort of development agent, agricultural experts, researchers and other stakeholders on identifying and solving problems, availing of new agricultural technology, transfers of improved technology and information to farmers are compulsory to enhance commercialization so as to improve livelihoods.

Integrate farmers to system of vegetable intensification by strengthening the existing provision of formal and informal education through facilitating all necessary materials; improve the existing tomato production and productivity system through adopting improved and recommended agricultural technology to increase productivity as well as commercialization.

Finally, developing market infrastructure through inaugurate the vegetable market center nearest to the farmer's residence or production area to decrease the perishability of the tomato, provision of marketing incentives to smallholder farmers are recommended to enhance commercialization of agriculture in area.

\section{Appendix}

Table A1. Multi-collinearity.

\begin{tabular}{lll}
\hline Variable & VIF & 1/VIF \\
\hline Oxen & 2.01 & 0.498161 \\
Extcontact & 1.91 & 0.524912 \\
Livestock & 1.80 & 0.556386 \\
Agesqrt & 1.77 & 0.566225 \\
Ltomato & 1.75 & 0.571944 \\
Productivity & 1.75 & 0.571986 \\
Education & 1.60 & 0.626649 \\
Texperience & 1.37 & 0.730317 \\
Fsize & 1.32 & 0.758958 \\
Marktdist & 1.19 & 0.840344 \\
Mean VIF & 1.64 & \\
\hline
\end{tabular}

Table A2. Contingency coefficient.

\begin{tabular}{lllllll}
\hline Variables & SexHH & Credit & Magrmt & Mcoop & LagPrice & Tvariety \\
\hline SexHH & 1.0000 & & & & & \\
Credit & 0.1874 & 1.0000 & & & & \\
Magrmt & 0.1042 & 0.2982 & 1.0000 & & & \\
Mcoop & 0.1658 & 0.1713 & 0.2462 & 1.0000 & & \\
LagPrice & 0.0496 & 0.1078 & 0.2136 & 0.0774 & 1.0000 & \\
Tvariety & 0.1098 & 0.3253 & 0.3223 & 0.2546 & 0.2749 & 1.0000 \\
\hline
\end{tabular}

Source: Computed based on model output.

\section{Acknowledgements}

First and for most, we would like to extend our unshared thanks to the almighty God, for the gift of life and good health, without which this work would not have been possible. Next we want to extend our immense thanks to Werabe University (WRU) for financially support and granted us to conduct this work.

\section{References}

[1] Ahmed, Y. E., Girma, A. B. and Aredo, M. K., 2016. Determinants of smallholder farmers participation decision in potato market in Kofele district, Oromia region, Ethiopia. International Journal of Agricultural Economics, 1 (2), pp. 40-44.

[2] Alemu, G., 2015. Market performance and determinants of marketed surplus of teff, in the case of Bacho woreda in south west shewa zone, Oromia national regional state (Thesis, Haramaya University, Haramaya, Ethiopia).

[3] Alamerie, K., 2016. Commercial Behaviour of Smallholder Potato Producers: The Case of Kombolchaworeda, Eastern Part of Ethiopia. Economics of Agriculture, 63 (1), pp. 159173.

[4] AVRDC (Asian Vegetable Research and Development Center), 2014. Scoping study on vegetables seed systems and Policy in Ethiopia, report.

[5] Benti, G., Degefa, G., Biri, A. and Tadesse, F., 2017. Performance Evaluation of Tomato (Lycopersicon esculentum Mill.) Varieties Under Supplemental Irrigation at Erer Valley, Babile District, Ethiopia. Journal of Plant Sciences, 5 (1), pp. $1-5$. 
[6] Binalfew, T., Alemu, Y., Geleto, J., Wendimu, G. and Hinsermu, M., 2016. Performance of introduced hybrid tomato (Solanum lycopersicum Mill.) cultivars in the Rift Valley, Ethiopia. International Journal of Research, pp. 1-25.

[7] Birhanu, K. and Keteme T., 2010. Fruit yield and quality of drip-irrigated tomato under deficit irrigation. African Journal of Food, Agriculture, Nutrition and Development, 10 (2).

[8] Cochran, W. G., 1977. Double sampling. Cochran WG. Sampling techniques. 3rd ed. New York: John Wiley \& Sons, Inc, pp. 327-58.

[9] Cragg, J. G., 1971. Some statistical models for limited dependent variables with application to the demand for durable goods. Econometrica: Journal of the Econometric Society, pp. 829-844.

[10] CSA (Central statistical Agency), 2018. Agricultural Sample Survey Report on Area and Production of Crops. Statical Bulletin 586, April, 2018, Addis Ababa.

[11] Demeke, L. and Haji, J., 2014. Econometric analysis of factors affecting market participation of smallholder farming in Central Ethiopia.

[12] Dessie, M., Woldeamanuel, T. and Mekonnen, G., 2017. Value chain analysis of red pepper: the case of Abeshge District, Guragie Zone, South Ethiopia. International Journal of Environmental Sciences and Natural Resources, 2 (3), pp. 94101 .

[13] FAOSTAT (Food and Agriculture Organization/Statistics), 2018. Statistical database of the Food and Agriculture Organization of the United Nations. FAO, Rome, Italy.

[14] Gebreselassie, S. and Ludi, E., 2008. Agricultural Commercialization in Coffee Growing Areas of Ethiopia, Future Agricultures.

[15] Gemechis, A. O., Struik, P. C. and Emana, B., 2012. Tomato production in Ethiopia: constraints and opportunities. Tropentag 2012, International Research on Food Security, Natural Resource Management and Rural Development. Resilience of Agricultural Systems against Crises: Book of Abstracts, 373.

[16] Getahun T. A., 2018. Determinants of commercialization and market outlet choice choices) of tef: the case of smallholder farmers in Dendi district of Oromia, Central Ethiopia (Doctoral dissertation, Haramaya University).

[17] Goshu, D., Tura, E. G., Demise, T. and Kenead, T., 2016. Determinants of market participation and intensity of marketed surplus of teff producers in Bacho and Dawo districts of Oromia State, Ethiopia. Forthcoming: Agricultural Economics.

[18] Gujarati, D. N., 2005. Basic econometrics (5 th Reprint).

[19] Heckman, J. J., 1979. Sample selection bias as a specification error. Econometrica: Journal of the econometric society, pp. 153-161.

[20] Kassa, G., Yigezu, E. and Alemayehu, D., 2017. Determinants of smallholder market participation among banana growers in bench Maji Zone, Southwest Ethiopia. International Journal of Agricultural Policy Research, 5, pp. 169-177.

[21] Kiprotich Sigei, G., 2014. Determinants of Market Participation Among Small-Scale Pineapple Farmers in
Kericho County, Kenya (No. 634-2016-41488).

[22] Leta, E. T., 2018. Determinants of commercialization of teff crop in Abay Chomen District, Horo Guduru wallaga zone, Oromia Regional State, Ethiopia. Journal of Agricultural Extension and Rural Development, 10 (12), pp. 251-259.

[23] Mbegallo, F. J., 2016. Status, determinants and effect of agriculture commercialization among smallholder farmers in Tanzania (Doctoral dissertation, Sokoine University of Agriculture).

[24] Mbitsemunda, J. P. K. and Karangwa, A., 2017. Analysis of factors influencing market participation of smallholder bean farmers in Nyanza district of Southern Province, Rwanda. Journal of Agricultural Science, 9 (11), pp. 99-111.

[25] Megerssa, G. R., Negash, R., Bekele, A. E. and Nemera, D. B., 2020. Smallholder market participation and its associated factors: Evidence from Ethiopian vegetable producers. Cogent Food \&. Agriculture, 6 (1), p. 1783173.

[26] Melese. W. and Samul. S., 2018. Review on Disease Management Practice of Tomato Wilt Caused Fusarium oxysporum in Case of Ethiopia. Journal of Plant Pathology and Microbiology. 9: 460.

[27] Melese, T., Dessie, A. B. and Abate, T. M., 2018. Determinants of commercialization by smallholder onion farmers in Fogera district, South Gondar Zone, Amhara national regional State, Ethiopia. Journal of Development and Agricultural Economics, 10 (10), pp. 339-351.

[28] MoA (Ministry of Agriculture). 2013. Animal and plant health regulatory directorate crop variety register. Issue No. 15. Addis Ababa, Ethiopia, pp: 180.

[29] Moono L., 2015. An Analysis of Factors Influencing Market Participation among Smallholder Rice Farmers in Western Province, Zambia. A Thesis Submitted In Partial Fulfillment of The Requirements for the Degree of Master of Science In Agricultural and Applied Economics.

[30] Moyo, T., 2010. Determinants of participation of smallholder farmers in the marketing of small grains and strategies for improving their participation in the Limpopo River Basin of Zimbabwe (Doctoral dissertation, University of Pretoria).

[31] Muricho, G. S., 2015. Determinants of agricultural commercialization and its impacts on welfare among smallholder farmers in Kenya (Doctoral dissertation, University of Nairobi).

[32] Ohen, S. B., Etuk, E. A. and Onoja, J. A., 2013. Analysis of market participation by rice farmers in southern Nigeria. Journal of Economics and Sustainable Development, 4 (7), pp. 6-11.

[33] Olwande, J. and Mathenge, M. K., 2011. Market participation among poor rural households in Kenya (No. 680-201646733).

[34] Osmani, A. G. and Hossain, E., 2015. Market participation decision of smallholder farmers and its determinants in Bangladesh. Economics of Agriculture, 62 (297-2016-3664), pp. 163-179.

[35] Sebatta, C., Mugisha, J., Katungi, E., Kashaaru, A. and Kyomugisha, H., 2014. Smallholder farmers' decision and level of participation in the potato market in Uganda. Modern Economy, 2014. 
[36] Sies, H., Stahl, W. and Sundquist, A. R., 1992. Antioxidant functions of vitamins: Vitamins E and C, Beta - Carotene, and other carotenoids a. Annals of the New York Academy of Sciences, 669 (1), pp. 7-20.

[37] Ssekyewa, C., 2006. Incidence, distribution and characteristics of major tomato leaf curl and mosaic virus diseases in Uganda (Doctoral dissertation, Ghent University).

[38] SZBoA (Siltie Zone Bureau of Agriculture), 2019. Socioeconomic profile description of Siltie Zone, Ethiopia.

[39] Teka, B. M., 2019. Determinants of Commercialization of Agricultural Products in East and West Gojjam, and Awi Zones, Amahara Region, Ethiopia.
[40] Tobin, J., 1952. A Survey of the Theory of Rationing. Econometrica: Journal of the Econometric Society, pp. 521553.

[41] Wickramasinghe, U. and Weinberger, K., 2013. Smallholder market participation and production specialization (No. 107). Working Paper.

[42] Woldesenbet, A. T., 2013. Value chain analysis of vegetables: the case of habro and Kombolcha woredas in Oromia region, Ethiopia. School of Agricultural Economics and Agribusiness School of Graduate Studies, Haramaya University. 